\title{
Four successful pregnancies in a woman after Fontan palliation: a case report
}

\author{
Rym Gribaa, Mehdi Slim*, Sana Ouali, Elies Neffati, Fehmi Remadi and Essia Boughzela
}

\begin{abstract}
Introduction: A Fontan operation is performed to provide palliation for patients with many forms of highly complex congenital heart disease that cannot support a biventricular circulation. Increasing numbers of women who have undergone these connections in childhood are now reaching their childbearing years, and some are becoming pregnant. The low flow and fixed cardiac output of a Fontan circulation poses several problems during pregnancy.

Case presentation: We report the case of four successful pregnancies in a 31-year-old Tunisian woman with congenital tricuspid atresia after Fontan operation. Her pregnancies resulted in delivery of four healthy neonates. Her clinical status remained unchanged.

Conclusions: This case suggests that patients after adequate Fontan palliation could complete pregnancy without long-term cardiac sequelae. Intensive care should be provided with specialists, including a neonatologist, anesthesiologist and cardiologist.
\end{abstract}

Keywords: Fontan circulation, Grown-up congenital heart disease, Pregnancy

\section{Introduction}

The Fontan operation was introduced as a palliative procedure for patients with tricuspid atresia and has since been used extensively to provide palliation for patients with several forms of congenital heart disease that cannot support biventricular circulation. The vena cava flow is directed to the pulmonary arteries without passing through the ventricle. It was initially described in 1971 [1]. Since then, the Fontan procedure has evolved over the years, most notably with the substitution of right atrialto-pulmonary artery anastomosis with cavopulmonary connections [2]. This progress resulted in significantly improved late outcomes; an increasing number of women who have undergone these connections in childhood are now surviving into adulthood, and some of them are becoming pregnant. Pregnancy after Fontan procedure has one of the highest risks in women with congenital heart disease and therefore requires careful prior consideration. Strict perinatal care is mandatory in these women. Reports on pregnancy in women with a prior Fontan connection

\footnotetext{
*Correspondence: mehdislim_fms@yahoo.fr

Department of Cardiology, Sahloul University Hospital, Sousse, Tunisia
}

are scarce. Here we describe four successful pregnancies in a woman after Fontan palliation.

\section{Case presentation}

We report the case of a 31-year-old Tunisian woman with a past medical history of congenital tricuspid atresia and pulmonary stenosis. In 1987, she underwent BlalockTaussig operation at the age of 5 years and Fontan operation at the age of 12 . The procedure included lateral atrial tunnel combined with bidirectional cavopulmonary anastomosis.

Recovery after treatment was uneventful. After surgery the patient was in New York Heart Association (NYHA) class I functional status. She was on vitamin K antagonists (acenocoumarol) for only 7 years: she withdrew from them herself. Contraception was advised and programmed pregnancy was recommended; however, she consulted when she was already pregnant. There is no ethical issue about medical termination of pregnancy in Tunisia. A summary of her four pregnancies is given in Table 1. She refused tubal ligation after her first pregnancy. Her clinical status was satisfactory during pregnancy. The pregnancies did neither cause any further limitation of her exercise capacity (NYHA I) nor episodes 
Table 1 Summary of the four pregnancies undergone by the patient

\begin{tabular}{ccccccccc}
\hline Year & $\begin{array}{c}\text { Age } \\
\text { (years) }\end{array}$ & $\begin{array}{c}\text { Complications } \\
\text { during pregnancy }\end{array}$ & $\begin{array}{c}\text { Term of delivery } \\
\text { (weeks) }\end{array}$ & $\begin{array}{c}\text { Route of } \\
\text { delivery }\end{array}$ & Baby sex & $\begin{array}{c}\text { Baby status } \\
\text { after birth }\end{array}$ & $\begin{array}{c}\text { Birth } \\
\text { weight (g) }\end{array}$ & $\begin{array}{c}\text { Complication } \\
\text { after delivery }\end{array}$ \\
\hline 1993 & 21 & None & 38 & Vaginal & Female & Good & 2900 & None \\
1998 & 26 & None & 37 & Vaginal & Female & Good & 2500 & None \\
1999 & 27 & Premature rupture of membranes & 32 & Vaginal & Male & Good & 2100 & None \\
2002 & 30 & None & 38 & Vaginal & Female & Good & 2600 & None \\
\hline
\end{tabular}

of supraventricular arrhythmia or thrombosis complications. The puerperia were uneventful without obstetric complications, especially postpartum hemorrhage. Fetal echocardiography, performed regularly during her four pregnancies, showed no congenital defects and no other abnormalities.

Currently the patient is in a good general condition and a NYHA functional class I. A physical examination revealed a regular heart rate of 75 beats per minute, oxygen saturation of $96 \%$, and no murmur nor signs of congestive cardiac failure. The 6-minute walk test showed good exercise tolerance. The findings of the electrocardiograms were sinus rhythm with incomplete left bundle branch block (Figure 1). Her echocardiography showed a preserved left ventricle ejection fraction of $69 \%$, without any significant atrioventricular regurgitation. Both atriums communicate by a large atrial septal defect. Doppler interrogation of the anastomosis revealed a laminar pattern (Figure 2). Her four children develop well and no abnormalities of their cardiovascular system were detected.

\section{Discussion}

In normal pregnancy with an increase in plasma volume, cardiac output continues to increase up to mid-pregnancy (30 to $40 \%$ above non-pregnant levels) as does circulating volume (up to 50\%) and heart rate (up to 25\%). For post-Fontan patients, the ability of the right atrium and functioning single ventricle to generate and tolerate the normal cardiovascular adjustment to pregnancy holds the key to successful pregnancy [3]. Hemodynamic changes observed during pregnancy especially increased heart rate, stroke volume and cardiac output with parallel reduction of vascular resistance are particularly disadvantageous in women after Fontan operation, due to their significant dependence on venous return and limited capability to increase the stroke volume. Such patients during pregnancy are at risk of heart failure, arrhythmias, ascites and even death caused by elevation of central venous pressure. Cardiac assessment during pregnancy should be made by echocardiography, electrocardiogram and brain natriuretic peptide [4]. They are also at risk of thrombosis and stroke. In fact, most patients after Fontan palliation need warfarin to prevent thrombosis in their surgically altered low flow circulation, and it should be substituted for unfractionated or low-molecular-weight heparin during pregnancy, especially during early and term pregnancy to prevent teratogenesis and to avoid excessive bleeding at labor due to warfarin [5]. Fetal complications were also observed. These complications were caused by the fixed low cardiac output that accompanies Fontan circulation. In fact low blood flow to the uterus and placenta could result in fetal growth restriction, non-reassuring fetal status and intolerance of labor due to metabolic disturbance [3]. Despite these complications, several small case series have been

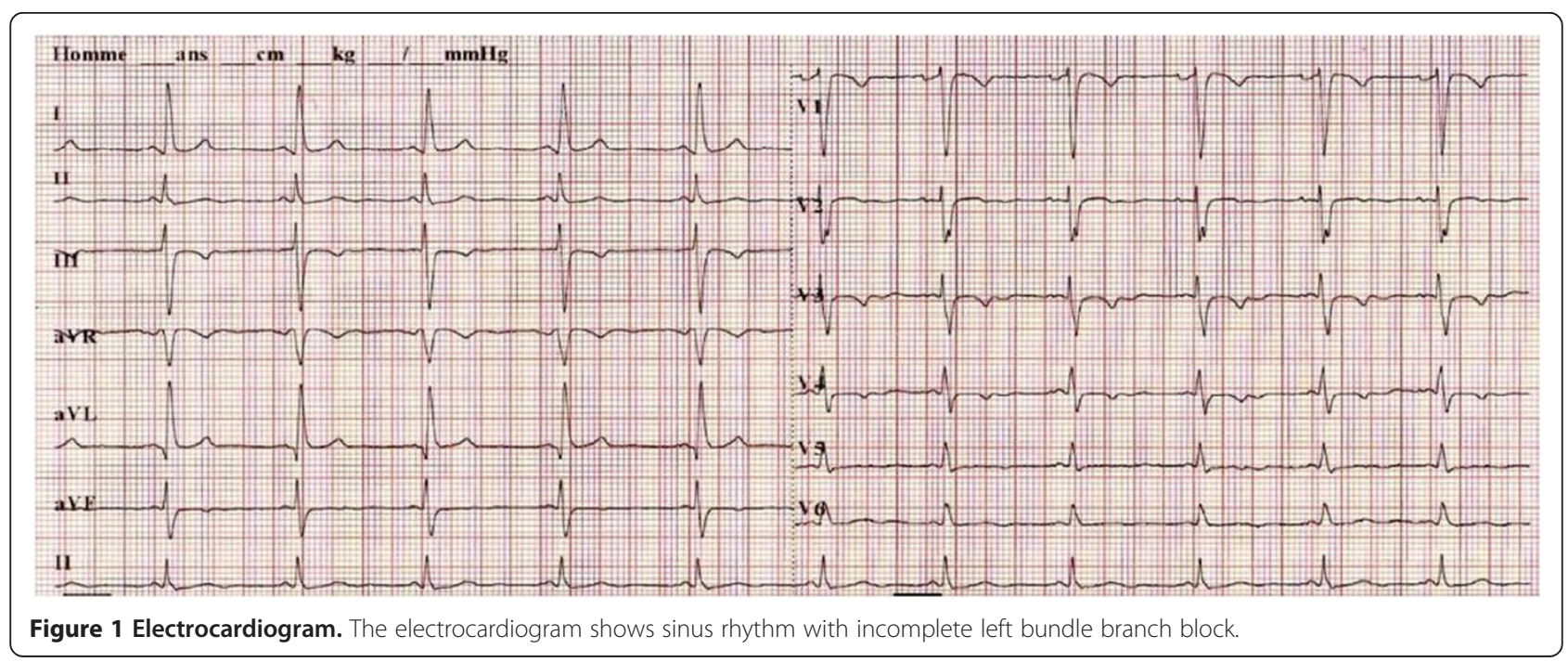




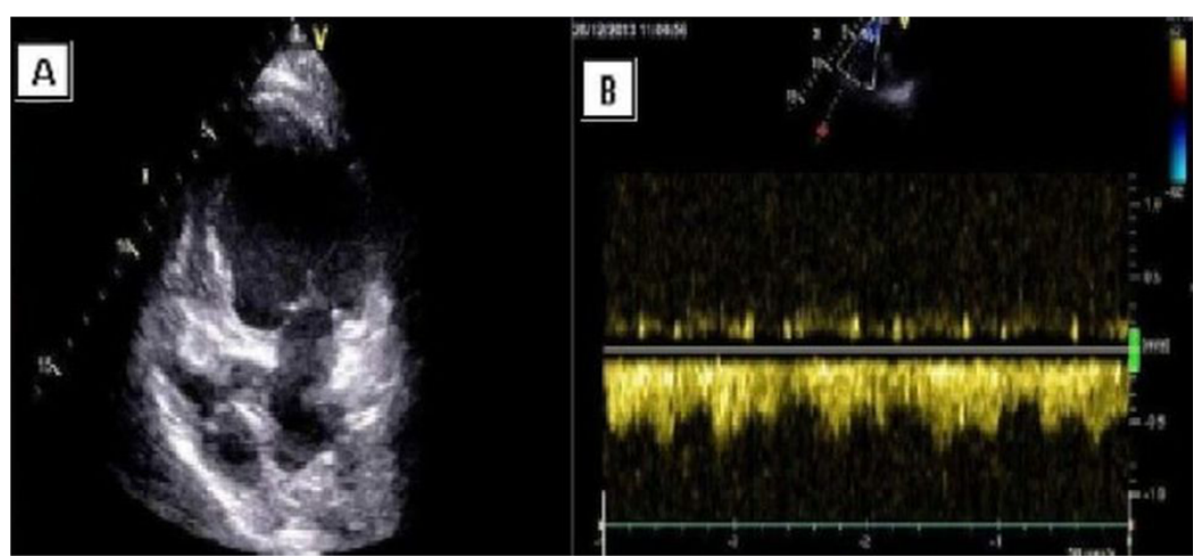

Figure 2 Transthoracic echocardiography. Panel A: Apical four chamber view showing tricuspid atresia. Panel B: Doppler interrogation of the anastomosis (superior vena cava to right pulmonary artery) revealed a laminar pattern.

reported in the literature with generally favorable results. To the best of our knowledge, this is the only case of four successful pregnancies in a woman after Fontan palliation resulting in normal delivery of four healthy neonates without significant complications. A summary of different case reports on pregnancy in women after Fontan procedure found in the literature is given in Table 2.

Because of the potential risk of complications of the Fontan pregnancy, delivery and peripartum management should be performed in a center with significant experience in the medical, obstetric, and anesthesiologic care of these patients. However, further studies are needed to determine the effect of the pregnancy on the survival of such patients.

\section{Conclusions}

Women can successfully complete pregnancy after adequate Fontan palliation without important long-term sequelae. Larger prospective studies or registries are needed to assess the outcome of pregnancies in patients with

Table 2 Overview of the literature on pregnancy after Fontan repair

\begin{tabular}{|c|c|c|c|c|c|c|c|}
\hline Authors (reference) & $\begin{array}{l}\text { Patients } \\
\text { (number) }\end{array}$ & $\begin{array}{l}\text { Completed } \\
\text { pregnancies }\end{array}$ & $\begin{array}{l}\text { Miscarriage/ } \\
\text { abortion }\end{array}$ & $\begin{array}{c}\text { Cardiac } \\
\text { complications }\end{array}$ & $\begin{array}{l}\text { Pregnancy } \\
\text { complications }\end{array}$ & $\begin{array}{c}\text { Obstetric } \\
\text { complications }\end{array}$ & $\begin{array}{c}\text { Neonatal } \\
\text { complications }\end{array}$ \\
\hline Girod et al. [6] & 1 & 1 & - & - & - & $\mathrm{PL}(1)$ & PD (1), SGA (1) \\
\hline Hess et al. [7] & 1 & 1 & - & SVT (1) & - & $\mathrm{PL}(1)$ & $\mathrm{PD}(1), \mathrm{ND}(1)$ \\
\hline Carmona et al. [8] & 1 & 1 & - & - & - & - & - \\
\hline Gerardin et al. [9] & 1 & 1 & - & $\operatorname{SVT}(1), \mathrm{HF}(1)$ & $\mathrm{PIH}(1)$ & $P L(1), F(1)$ & $\mathrm{PD}(1)$ \\
\hline Carp et al. [10] & 2 & 2 & $1 /-$ & AFL/AF (1) & - & CS (1), PROM (1), PPH (1) & PD (2), SGA (1) \\
\hline $\begin{array}{l}\text { Cohen and } \\
\text { Mulvein [11] }\end{array}$ & 1 & 1 & - & AFL/AF (1) & - & $\operatorname{PROM}(1), \mathrm{PL}$ (1) & PD (1), ND (1) \\
\hline Osmers et al. [12] & 1 & 1 & - & - & VAG (1) & CS (1) & $\mathrm{PD}(1)$ \\
\hline Lao et al. [13] & 1 & 1 & - & - & VAG (1) & PROM (1), PL (1), PPH (1) & PD (1) \\
\hline Canobbio et al. [3] & 21 & 15 & $13 / 5$ & $\begin{array}{l}\text { SVT (1), HF (1), } \\
\text { NYHA } \downarrow \text { (1) }\end{array}$ & - & CS (11), PROM (1), PL (1) & $\mathrm{CHD}(1), \mathrm{PD}(1)$ \\
\hline Grunwald et al. [14] & 1 & 1 & - & - & - & $\mathrm{PPH}(1)$ & SGA (1) \\
\hline $\begin{array}{l}\text { Hoare and } \\
\text { Radford [15] }\end{array}$ & 3 & 4 & $5 / 2$ & AFL/AF (2), NYHA $\downarrow$ (1) & - & CS (2), PROM (1), PL (1) & PD (4) \\
\hline Siu et al. [16] & 5 & 5 & - & AFL/AF (2), NYHA $\downarrow$ (2) & - & - & - \\
\hline Ito et al. [17] & 1 & 1 & - & - & - & $\operatorname{CS}(1)$ & SGA (1) \\
\hline Drenthen et al. [18] & 38 & 4 & $5 / 1$ & AFL/AF (1), NYHA $\downarrow$ (2) & VAG (1), PIH (1) & $\begin{array}{l}\mathrm{CS}(3), \mathrm{F}(1), \mathrm{PL}(1) \\
\mathrm{PROM}(1), \mathrm{PPH}(1)\end{array}$ & $\begin{array}{c}\text { PD (2), SGA (2), } \\
\text { ND (1) }\end{array}$ \\
\hline Overall & 78 & 39 & $24 / 8$ & $\begin{array}{c}\text { AFL/AF (7), NYHA } \downarrow \text { (6), } \\
\text { SVT (3) HF (2) }\end{array}$ & VAG (3), PIH (2) & $\begin{array}{c}\mathrm{CS} \text { (19), PL (8), PROM (6), } \\
\text { PPH (4), F (2) }\end{array}$ & $\begin{array}{l}\text { PD (15), SGA (5), } \\
\text { ND (3), CHD (1) }\end{array}$ \\
\hline
\end{tabular}

$\mathrm{AF}$, atrial fibrillation; $\mathrm{AFL}$, atrial flutter; $\mathrm{CHD}$, congenital heart disease; $\mathrm{CS}$, caesarean section; $\mathrm{F}$, forceps delivery; $\mathrm{HF}$, heart failure; ND, neonatal death; NYHA $\downarrow$, New York Heart Association class deterioration; PD, premature delivery; PIH, pregnancy-induced hypertension; $\mathrm{PL}$, premature labor; $\mathrm{PPH}$, postpartum hemorrhage; PROM, premature rupture of membranes; SGA, small for gestational age; SVT, supraventricular tachycardia; VAG, vaginal bleeding. 
congenital heart disease, especially those with complex anomalies and Fontan palliation.

\section{Consent}

Written informed consent was obtained from the patient for publication of this case report and any accompanying images. A copy of the written consent is available for review by the Editor-in-Chief of this journal.

\section{Abbreviations}

NYHA: New York Heart Association.

\section{Competing interests}

The authors declare that they have no competing interests.

\section{Authors' contributions}

RG drafted the manuscript. MS contributed in collecting of data. OS contributed in writing the manuscript. EN contributed in correcting the manuscript. FR contributed in correcting the manuscript. EB contributed in analysis, in interpretation of data, in the writing of the manuscript and in the decision to submit the manuscript for publication. All authors read and approved the final manuscript.

\section{Received: 22 June 2014 Accepted: 18 August 2014}

Published: 21 October 2014

\section{References}

1. Fontan F, Baudet E: Surgical repair of tricuspid atresia. Thorax 1971, 26:240-248.

2. Reul GJ, Gregoric ID: Recent modifications of the Fontan procedure for complex congenital heart disease. Tex Heart Inst J 1992, 19:223-242.

3. Canobbio MM, Mair DD, van der Velde M, Koos BJ: Pregnancy outcomes after the Fontan repair. J Am Coll Cardiol 1996, 28:763-767.

4. Tanous D, Siu SC, Mason J, Greutmann M, Wald RM, Parker JD, Sermer M, Colman JM, Silversides CK: B-type natriuretic peptide in pregnant women with heart disease. J Am Coll Cardiol 2010, 56:1247-1253.

5. Barbour LA: Current concepts of anticoagulant therapy in pregnancy. Obstet Gynecol Clin North Am 1997, 24:499-521.

6. Girod DA, Fontan F, Deville C, Ottenkamp J, Choussat A: Long-term results after the Fontan operation for tricuspid atresia. Circulation 1987, 75:605-610

7. Hess DB, Hess LW, Heath BJ, Lehan PH, McColgin SW, Martin JN Jr, Morrison JC: Pregnancy after Fontan repair of tricuspid atresia. South Med J 1991, 84:532-534.

8. Carmona F, Martinez S, Periz A, Cararach V: Pregnancy after surgical correction of tricuspid atresia. Acta Obstet Gynecol Scand 1993, 72:498-499.

9. Gerardin B, Houyel L, Discazeaux B, Farhi P, Estampes B: Successful pregnancy after Fontan procedure complicated by recurrent junctional tachycardia. Arch Mal Coeur Vaiss 1993, 86:935-938.

10. Carp H, Jayaram A, Vadhera R, Nichols M, Morton M: Epidural anesthesia for cesarean delivery and vaginal birth after maternal Fontan repair: report of two cases. Anesth Analg 1994, 78:1190-1192.

11. Cohen AM, Mulvein J: Obstetric anaesthetic management in a patient with the Fontan circulation. Br J Anaesth 1994, 73:252-255.

12. Osmers R, Osmers M, Bartmus D, Ruschewski W, Kuhn W: Normal pregnancy duration after maternal Fontan operation of univentricular heart. Z Geburtshilfe Neonatol 1995, 199:195-198.

13. Lao TT, Sermer M, Colman JM: Pregnancy after the Fontan procedure for tricuspid atresia: a case report. J Reprod Med 1996, 41:287-290.

14. Grunwald Z, Friedman L, Hirsch R, Doron K: Anesthetic management of labor and postpartum bleeding in a patient with Fontan physiology. Isr J Med Sci 1997, 33:749-751.

15. Hoare $\mathrm{JV}$, Radford D: Pregnancy after Fontan repair of complex congenital heart disease. Aust N Z J Obstet Gynaecol 2001, 41:464-468.

16. Siu SC, Sermer M, Colman JM, Alvarez AN, Mercier LA, Morton BC, Kells CM, Bergin ML, Kiess MC, Marcotte F, Taylor DA, Gordon EP, Spears JC, Tam JW, Amankwah KS, Smallhorn JF, Farine D, Sorensen S: Prospective multicenter study of pregnancy outcomes in women with heart disease. Circulation 2001, 104:515-521.
17. Ito M, Takagi N, Sugimoto S, Oosawa H, Abe T: Pregnancy after undergoing the Fontan procedure for a double outlet right ventricle: report of a case. Surg Today 2002, 32:63-65.

18. Drenthen W, Pieper PG, Roos-Hesselink JW, Zoon N, Voors AA, Mulder BJ van Dijk AP, Vliegen HW, Sollie KM, Ebels T, van Veldhuisen DJ, ZAHARA Investigators: Fertility, pregnancy, and delivery after biventricular repair for pulmonary atresia with an intact ventricular septum. Am J Cardiol 2006, 98:259-261.

doi:10.1186/1752-1947-8-350

Cite this article as: Gribaa et al:: Four successful pregnancies in a woman after Fontan palliation: a case report. Journal of Medical Case Reports 2014 8:350.

\section{Submit your next manuscript to BioMed Central and take full advantage of:}

- Convenient online submission

- Thorough peer review

- No space constraints or color figure charges

- Immediate publication on acceptance

- Inclusion in PubMed, CAS, Scopus and Google Scholar

- Research which is freely available for redistribution 